\title{
Effect of Intellectual Capital, Corporate Sustainability Disclosure, and Corporate Governance To The Value of The Company: Empirical Study on Registered SOE in Indonesia Stock Exchange
}

\author{
Kenny Ardillah \\ Universitas Bunda Mulia \\ kennyardillah121@gmail.com
}

\begin{abstract}
*
The main purpose of the company's operation today is to maximize the value of the company. Corporate value is not only influenced by economic performance, but can come from performance derived from social activities. But in reality, it eventually leads to a conflict of interest that occurs within the company, so that necessary to implement mechanisms to reduce the conflict. The purpose of this research to provide evidence to determine effect of intellectual capital, corporate sustainability disclosure, and corporate governance to corporate values with company size and leverage as control variables. This research can provide benefits as knowledge related to how wide the company pursues intellectual capital, corporate social responsibility, and corporate governance in increasing the value of the company. This research samples is focused on stateowned enterprises listed in Indonesia Stock Exchange for period 2013 - 2016 with total 48 data used in this research. This research use multiple regression to test the hypothesis. The result of this research is intellectual capital and corporate sustainability disclosure have positively influence towards corporate values. Corporate governance has no influence towards corporate values. For control variables, company size has no influence towards corporate values and leverage has negatively influence towards corporate values.
\end{abstract}

Keywords: Corporate Governance, Corporate Sustainability Disclosure, Corporate Values, Intellectual Capital

\begin{abstract}
Abstrak
Tujuan utama dari operasi perusahaan saat ini adalah untuk memaksimalkan nilai perusahaan. Nilai perusahaan tidak hanya dipengaruhi oleh kinerja ekonomi, tetapi dapat berasal dari kinerja yang berasal dari kegiatan sosial. Namun kenyataannya, pada akhirnya mengarah pada konflik kepentingan yang terjadi di dalam perusahaan, sehingga perlu untuk menerapkan mekanisme untuk mengurangi konflik. Tujuan penelitian ini untuk memberikan bukti untuk mengetahui pengaruh modal intelektual, pengungkapan keberlanjutan perusahaan, dan tata kelola perusahaan terhadap nilai-nilai perusahaan dengan ukuran perusahaan dan leverage sebagai variabel kontrol. Penelitian ini dapat memberikan manfaat sebagai pengetahuan yang berkaitan dengan seberapa luas perusahaan mengejar modal intelektual, tanggung jawab sosial perusahaan, dan tata kelola perusahaan dalam meningkatkan nilai perusahaan. Sampel penelitian ini difokuskan pada perusahaan milik negara yang terdaftar di Bursa Efek Indonesia untuk periode 2013 - 2016 dengan total 48 data yang digunakan dalam penelitian ini. Penelitian ini menggunakan regresi berganda untuk menguji hipotesis. Hasil dari penelitian ini adalah intellectual capital dan corporate sustainability disclosure berpengaruh positif terhadap nilai-nilai perusahaan. Tata kelola perusahaan tidak memiliki pengaruh terhadap nilai-nilai perusahaan. Untuk variabel kontrol, ukuran perusahaan tidak memiliki pengaruh terhadap nilainilai perusahaan dan leverage memiliki pengaruh negatif terhadap nilai-nilai perusahaan.

Kata Kunci: Tata Kelola Perusahaan, Pengungkapan Keberlanjutan Perusahaan, Nilai-Nilai Perusahaan, Modal Intelektual

*) The full paper version of the article is published first time in this jurnal. Abstract (only) version is in the proceeding of KIA V Conference, March 2018.
\end{abstract}

\section{Introduction}

Berzkalne and Zelgalve (2014) stated the main purpose of the company's operations is to maximize the value of the company. The value of the company becomes an indication of the company's success rate in increasing investor investment confidence. This is reflected in the increase in the company's stock price. Corporate value is strongly influenced by stock price movements arising from investment opportunities that investors expect (Kurniasari and Warastuti, 2015). For example, during 2016 PT Bank Mandiri Tbk recorded an increase in share price by $29 \%$ and an increase in market capitalization by $25 \%$. Investors' confidence in the company's performance is due to its optimism that the company will increase its profitability and problem solving ratio of non-performing loans (Setiawan, 2017).

According to Kamath (2015), the value of the firm is not derived from financial assets and has a form, but can also come from other assets that have no form. The increasingly tight business competition and the rapid development of information technology economics require companies to start depending on the company's ability to develop intangible assets (Berzkalne and Zelgalve, 2014). Intellectual capital becomes an important source of knowledge assets for the company to enhance the company's competitive advantage in the future $(\mathrm{Nu}-$ ryaman, 2015).

The concept of sustainable development of improving the quality of life is the main focus of today's countries 
to reduce emissions and improve efficiency on energy consumption. One of the concrete evidence that has a major impact on the environment is the European Union that successfully implemented the development of environmentally friendly energy resources (Ghergina and Vintila, 2016). Corporate sustainability disclosure is the responsibility that companies must meet in terms of reporting that has shifted from a single bottom line focusing on raising corporate value from financial to a triple bottom line focusing on improving corporate value from financial, social and environmental conditions ( Kurniasari and Warastuti, 2015).

In the process of maximizing corporate value, there is often a conflict of interest that occurs between the management that controls the company and the shareholders who own the company.. This creates an agency fee that needs to be issued by shareholders for management to act in the interests of shareholders (Jensen and Meckling, 1976). One mechanism that companies can use to monitor relationships and lower agency costs is corporate governance. Corporate governance becomes the guiding structure in determining corporate objectives and monitoring the performance of management in implementing policies that facilitate the improvement of corporate value (Haryono and Paminto, 2015)

Berzkalne and Zelgalve (2014) in his research proved that intellectual capital has a positive and significant effect on company value. Gherghina and Vintila (2016), Kurniasari and Warastuti (2015), Moeljadi (2014), and Putu, et.al (2014) prove that corporate sustainability disclosure has a significant effect on corporate value. Haryono and Paminto (2015) proves corporate governance does not affect the value of the company. Moeljadi (2014) and Putu, et.al (2014) prove that corporate governance has a positive effect on company value.

The motivation of this research is to determine whether or not there is influence of intellectual capital, corporate sustainability disclosure, and corporate governance to the value of the company with the current phenomenon. This study aims to prove empirically the influence of individually intellectual capital, corporate sustainability disclosure, and corporate governance on corporate value controlled by firm size and leverage. Based on this background, the authors examine the influence of intellectual capital, corporate sustainability disclosure, and corporate governance affect the value of the company with the title "The Influence of Intellectual Capital, Corporate Sustainability Disclosure, Corporate Governance, Corporate Value: Empirical Study on BUMN Listed in Indonesia Stock Exchange."

\section{Theoretical Framework and Hypothesis Develop- ment}

\section{Theoretical Framework Agency Theory}

Any people as well as organization in the world need foAccording to Jensen \& Meckling (1976), in the agency relationship there is a separation of interests between the company owner (principal) and the manager of the company (agent). Shareholders give full authority to managers to run the company. But managers also have an interest to improve their own welfare. This has led to agency conflicts in companies that have led to opportunistic behavior of managers to gain personal gain. One of the methods used to monitor agency relations is through corporate governance mechanisms that can reduce the agency costs incurred by the company.

\section{Stakeholder Theory}

Haryono and Paminto (2015) argue that stakeholder theory is a business ethical theory that implements the principles and values in management which change from a traditional financial perspective to maximize shareholder value into stakeholder perspectives to maximize stakeholder value. Dewi and Monalisa (2016) stated that the company is required to carry out social responsibility activities that can legitimize the company's actions in the community in carrying out its operations. Companies that disclose social responsibility information in full and have social activities will gain legitimacy from society that ultimately increases the value of the company.

\section{The Value of the Company}

The value of the company is reflected in the stock price which also reflects the reflection of the market value of the firm formed from the transaction between the buyer and the seller. The value of a company is a reflection of the true value of a company's assets formed from the value of the indicators affected by the stock market investment opportunity.. The existence of investment opportunities can provide a positive signal about future company growth that can increase shareholder value (Kurniasari and Warastuti, 2015).

\section{Intellectual Capital}

Steward (1997) in Nuryaman (2015) states that intellectual capital is an intangible asset owned by a company that can be knowledge, information, and experience owned by human resources company. Intellectual capital is divided into three dimensions, namely human capital in the form of intellectual capability, structured capital in the form of infrastructure that supports company performance or innovation to develop processes, products, and services, and external capital in the form of relationships with internal and external parties.

\section{Corporate Sustainability Disclosure}

Moeljadi (2014) states that corporate sustainability disclosure based on ISO 26000 is the responsibility of an organization or the influence of organizational decisions and activities that directly affect the social life of society and the environment. GRI (2013) provides globally relevant frameworks to support standardized approaches in reporting social responsibility information that encourages the level of transparency and consistency necessary to make the information conveyed to be useful and credible by markets and communities. In the GRI-G4 Guidelines, performance indicators are divided into 3 main components, namely economic, environmental, and social including employment practices and work convenience, 
human rights, community, responsibility for products with total performance reaching 91 indicators.

\section{Corporate Governance}

OECD (2004) defines corporate governance as a system in which a company or business entity is directed and supervised by a structure that explains the distribution of rights and responsibilities of each party involved in a business. The following are the principles of OECD (2004) which underlie the measurement of the level of corporate governance implementation in the company.

1. Ensure an effective corporate governance framework

2. Shareholder rights and important shareholding functions

3. Equal treatment of shareholders

4. The role of stakeholders in corporate governance

5. Openness and transparency

6. Responsibility of board of commissioners and directors

\section{Leverage}

According to Nadeem, et.al (2016), leverage is the use of financial resources in the firm's capital structure. Leverage is one of the sources of funding for companies in the form of debt (short term debt and long term debt) or capital (preffered stock and common stock). Leverage in a company is determined from optimal corporate capital structure policy in minimizing risk and cost.

\section{Company Size}

Company size describes how big or small a company is shown from total assets, total sales, total average sales, and total average assets. The size of the firm also shows the large amount of resources owned by the company and becomes an important indicator for investors and creditors in determining investment risk on capital invested into a company (Putu, et al, 2014).

\section{Pengembangan Hipotesis Intellectual Capital Influence on Corporate Value}

Nuryaman (2015) states that in the application of intellectual resource management must create intellectual resources of capital, human resources, and structural capital employed that can be optimally utilized. These intellectual resources can ultimately help facilitate the company in the fulfillment of all stakeholder interests. Companies that have intellectual resources with high corporate share demand will increase the value of the company.

H1: Intellectual capital positively affects the value of the company

\section{The Effect of Corporate Sustainability Disclosure on Corporate Value}

Gherghina and Vintila (2016) states based on the theory of legitimacy, in carrying out its operations the company needs to pay attention to the interests of stakeholders.
The availability of social responsibility information becomes the company's need to meet the interests of stakeholders in providing support to the company. Companies that invest heavily in social responsibility activities can maintain a better corporate reputation resulting in increased corporate value.

H2: Corporate sustainability disclosure positively affects the value of the company

\section{The influence of Corporate Governance on Corporate Value}

Moeljadi (2014) declares corporate governance to be a system used to direct and manage the company's operating activities that have a major impact in determining business objectives to achieve targets. Wardoyo and Veronika (2013) states that based on agency theory there can be a difference of interests between managers and shareholders that can lead to agency conflicts. In reducing the conflict of agencies that can arise, companies can run corporate governance to control the behavior of managers who can improve the performance and value of the company.

H3: Corporate governance positively affects the value of the company

\section{Research Method \\ Research Procedure}

The population of this study are all companies listed on the Indonesia Stock Exchange respectively from 2013-2016. The sample of this research is all state-owned enterprises of financial and non financial sector listed on Indonesia Stock Exchange respectively from year 20132016. The method of selecting the research sample used in this study using purposive sampling. The selection criteria of this research sample as follows.

1. State-owned enterprises in the financial and non-financial sector listed on the Indonesia Stock Exchange from 2013-2016.

2. Companies that issue financial statements at the end of the fiscal year 31 December from 20132016.

3. Companies that generate financial reports in rupiah currency from 2013-2016.

4. Companies disclosing reporting of social responsibility activities under GRI G4 from 2013-2016.

\section{Variable Operationalization \\ The value of the company}

Company value is measured using tobin's q ratio introduced by James Tobin (1969) which can better explain the performance of a company. The ratio of tobin's q in measurement is replicated from Berzkalne and Zelgalve (2014) using the measurement of tobin's ratio q by Jin and Jorion (2006). The scale used in measuring firm value is the ratio scale.

The population of this study are all companies listed on the Indonesia Stock Exchange respectively from 2013- 
Figure 1. Research Model

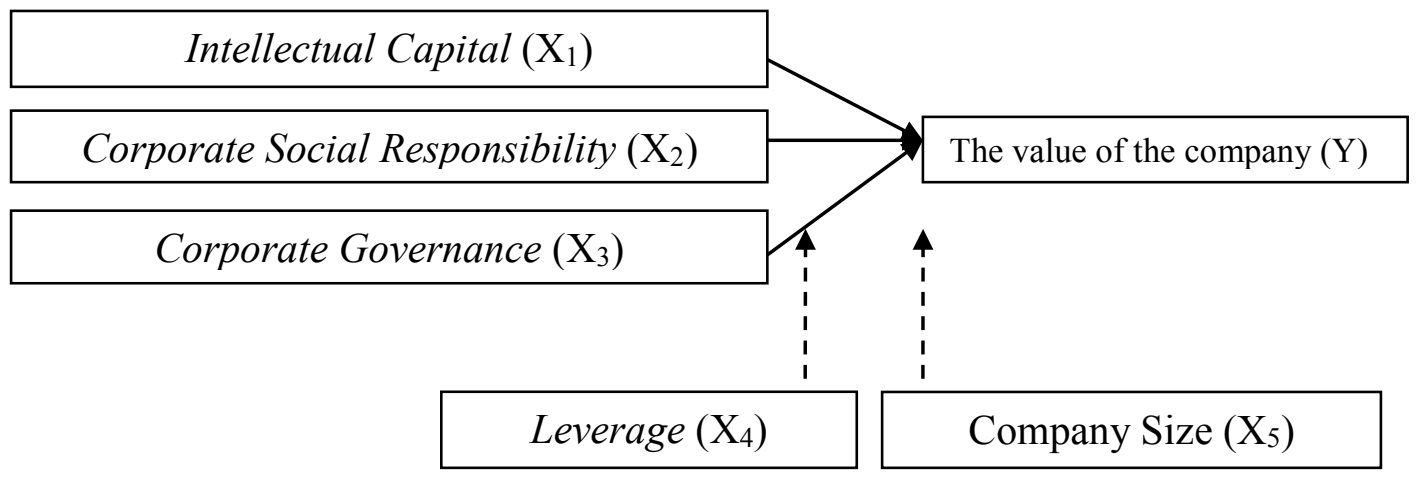

2016. The sample of this research is all state-owned enterprises of financial and non financial sector listed on Indonesia Stock Exchange respectively from year 20132016. The method of selecting the research sample used in this study using purposive sampling. The selection criteria of this research sample as follows.

1. State-owned enterprises in the financial and nonfinancial sector listed on the Indonesia Stock Exchange from 2013-2016.

2. Companies that issue financial statements at the end of the fiscal year 31 December from 20132016.

3. Companies that generate financial reports in rupiah currency from 2013-2016.

4. Companies disclosing reporting of social responsibility activities under GRI G4 from 2013-2016.

\section{Variable Operationalization}

The value of the company

Company value is measured using tobin's q ratio introduced by James Tobin (1969) which can better explain the performance of a company. The ratio of tobin's q in measurement is replicated from Berzkalne and Zelgalve (2014) using the measurement of tobin's ratio q by Jin and Jorion (2006). The scale used in measuring firm value is the ratio scale.

Tobin's $\mathrm{Q}=\underline{\mathrm{BV} \text { total assets }-\mathrm{BV} \text { common }}$ equity + MV common equity

BV total assets

Book Value Common Equity $=$ Par value $\mathrm{x}$ number of outstanding share

Market Value Common Equity $=$ Closing price $\mathrm{x}$ number of outstanding shares

\section{Intellectual Capital}

Intellectual capital measured by Value Added Intelectual Coefficient (VAIC) proxy is developed by Pulic (1999) replicated from Nuryaman (2015). Value Added Intelectual Coefficient (VAIC) shows how much new value can be created for each unit of monetized resources invested. Stages of calculation to obtain Value Added Intelectual Coefficient (VAIC) is as follows.

1. Determining Value Added (VA). $\mathrm{VA}=\mathrm{OP}+\mathrm{HC}+$ $\mathrm{D}+\mathrm{A}: \mathrm{OP}=$ operating profit $\mathrm{HC}=$ personnel load;
$\mathrm{D}=$ depreciation; $\mathrm{A}=$ amortization.

2. Determine the Value Added Capital Employed (VACA). VACA is a VA measurement produced by one unit of physical capital. VACA $=\mathrm{VA} / \mathrm{CE}$. $\mathrm{CE}=$ available funds derived from net income and equity.

3. Determine the Value Added Human Capital (VAHU). VAHU is a VA indicator generated from each dollar invested into HC. VAHU = VA / HC.

4. Determining Strutured Capital Value Added (STVA). STVA indicates the amount of SC that a company can use to generate a VA dollar. STVA = $\mathrm{SC} / \mathrm{VA} . \mathrm{SC}=\mathrm{VA}-\mathrm{HC}$

5. Determine the Value Added Intelectual Coefficient (VAIC). VAIC is the sum of the three components that have been calculated before the VACA, VAHU, and STVA. VAIC $=$ VACA + VAHU + STVA.

\section{Corporate Sustainability Disclosure}

Corporate sustainability disclosure is measured by proxy Sustainability Reporting Disclosure Index with disclosure category which refers to GRI G4.0 guidelines with a total of 91 items. Index measurements are scored with criteria if the item is assigned a value of 1 and is not available given a value of 0 . Sustainability Reporting Disclosure Index is calculated through the sum of all items disclosed by the company divided by the whole item. The scale used in measuring corporate sustainability disclosure is the nominal scale.

\section{Corporate Governance}

Corporate governance is measured by the proxy of corporate governance scoring index of disclosure categories based on the General Guidelines of Good Corporate Governance (2006) containing 16 categories containing 103 items. In measuring the index is done by providing scoring with the criteria for each available subindex given point 1 if fulfilled and 0 if not met. Corporate governance scoring index can be calculated by dividing the total score of corporate governance disclosure indicators with the overall corporate governance disclosure score. The scale used in measuring corporate governance is the nominal scale. 
Table 1. Results of Sample Selection Procedures

\begin{tabular}{llll}
\hline No. & Description of Criteria & $\begin{array}{l}\text { Number of } \\
\text { Companies }\end{array}$ & $\begin{array}{l}\text { Amount } \\
\text { of data }\end{array}$ \\
\hline 1. $\quad \begin{array}{l}\text { Financial and non-financial BUMN companies listed on the } \\
\text { Indonesia Stock Exchange in a row from 2013-2016. }\end{array}$ & 20 & 80 \\
2. $\quad \begin{array}{l}\text { Companies that do not issue financial statements at the end of } \\
\text { the December 31 fiscal year in a row from 2013-2016. }\end{array}$ & $(0)$ & $(0)$ \\
$\begin{array}{l}\text { Companies that do not issue financial statements in rupiah in a } \\
\text { row from 2013-2016. }\end{array}$ & $(3)$ & $(12)$ \\
$\begin{array}{l}\text { Companies that do not disclose reporting of social responsibility } \\
\text { activities based on GRI G4 respectively from 2013-2016. }\end{array}$ & $(5)$ & $(20)$ \\
\hline Number of samples & 12 & 48 \\
\hline
\end{tabular}

\section{Leverage}

The measured leverage measurement from Gherghina (2015) measures leverage through the proxy of debt to total equity ratio by comparing total debt and total equity of the firm. The scale used in measuring leverage is the ratio scale.

\section{Company Size}

The size of the company in its measurement is replicated from Moeljadi (2014) which measures firm size based on the total natural logarithm of the asset. The scale used in measuring firm size is the ratio scale.

\section{Hypothesis testing}

The multiple regression model used to test the hypothesis of this study is translated into linear function in the form of equation as follows. VALUE $=\alpha+\beta 1 \mathrm{IC}+\beta 2 \mathrm{CSD}+\beta 3 \mathrm{CG}+\beta 4 \mathrm{UK}+\beta 5$ LEV

\section{Result, Discussion, and Managerial Implication Result \\ Data Presentation}

Table 1 shows that there are 12 state-owned enterprises in the financial and non-financial sectors of 20 SOE companies selected to be research samples with a 4-year study period from 2013-2016, so that the total amount of data used in this research is 48 data.Statistik Deskriptif

Table 2 shows the total data used as the sample in this study is 48 data. The value of the company in a stateowned enterprise measured by tobin's q ratio has a minimum value of PT Bank Tabungan Negara Persero Tbk in 2013 of 1.0298 and maximum value in PT Semen In- donesia Persero Tbk in 2014 amounting to 3.7829. The average value of the company's value in state-owned enterprises in 2013-2016 amounted to 1.7988. These data indicate that the average value of firms in state-owned companies in Indonesia is greater than 1 indicating the market rate of stock prices in the market for SOE companies is too high.

Intellectual capital is measured by the proxy of Value Added Intellectual Coefficient (VAIC) of BUMN companies having minimum value of 1.1798 in 2015 at PT Aneka Tambang Persero Tbk and maximum value at PT Semen Indonesia Persero Tbk in 2013 amounting to 9.5214. The average value of intellectual capital of stateowned enterprises in 2013-2016 amounted to 4.6106. This shows that the average intellectual capital in stateowned companies is high is greater than 1 indicating that state-owned enterprises have paid attention to the use of intellectual capital resources in support of the creation of corporate value.

Corporate sustainability disclosure is measured by Sustainability Reporting Disclosure Index proportion of SOE companies having a minimum value of 0.0769 at PT Adhi Karya Persero Tbk in 2013 and maximum value of PT Bukit Asam Persero Tbk in 2015 of 0.9670 . The average corporate sustainability disclosure value of BUMN companies in 2013-2016 is 0.3784 . This indicates that the average corporate sustainability disclosure disclosure rate of less than $50 \%$ indicates that the SOE company has not paid attention to the disclosure of corporate sustainability disclosure widely because of its mandatory disclosure and disclosure that have not effectively impacted firm value.

Corporate governance as measured by Corporate Gov-

Table 2. Descriptive Statistics

\begin{tabular}{lllll}
\hline Variabel & N & Minimum & Maximum & Average \\
\hline VALUE & 48 & 1,0298 & 3,7829 & 1,7988 \\
IC & 48 & 1,1798 & 9,5214 & 4,6106 \\
CSD & 48 & 0,0769 & 0,9670 & 0,3784 \\
CG & 48 & 0,7378 & 1,0000 & 0,8847 \\
UK & 48 & 29,7405 & 34,5767 & 31,8540 \\
LEV & 48 & 0,2361 & 11,3958 & 2,9122 \\
\hline
\end{tabular}

Source : Output SPSS version 21.0 
Tabel 3. $T$ Test Results

\begin{tabular}{llccl}
\hline \multicolumn{1}{c}{ Variable } & Koefisien & T & Sig. & \multicolumn{1}{c}{ Decision } \\
\hline Konstanta & $-0,838$ & $-0,506$ & 0,615 & \\
IC & 0,289 & 3,995 & 0,000 & Have a positive influence \\
CSD & 0,969 & 3,020 & 0,004 & Have a positive influence \\
CG & 2,246 & 1,461 & 0,151 & Have no influence \\
UK & $-0,023$ & $-0,302$ & 0,764 & Have no influence \\
LEV & $-0,113$ & $-4,073$ & 0,000 & Have a negative influence \\
\hline
\end{tabular}

Source : Output SPSS version 21.0

ernance Scoring Index proxy has minimum value at PT Timah Persero Tbk in 2013 amounted to 0.7378 and maximum value in PT Bank Negara Indonesia Tbk year 2016 amounting to 1 . The average corporate governance value of SOE companies in 2013-2016 of 0.8847. This shows that the average level of corporate governance corporate disclosure of SOEs is more than $50 \%$. This indicates that SOE companies have noticed corporate governance disclosure that is already mandatory disclosure.

The size of the company is proxied from total assets having minimum asset value at PT Timah Persero Tbk in

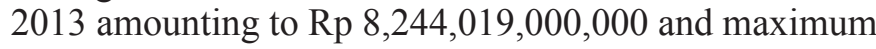
value of total assets at PT Bank Mandiri Tbk in 2016 amounting to $\mathrm{Rp} 1,038,706.009,000,000.00$. The average value of the total assets of state-owned enterprises in 2013-2016 amounted to Rp148,014,281,800,442. This shows that the total assets owned by the company can illustrate the size of the company. Leverage measured by the proxy of debt to equity ratio has a minimum value of DER at PT Bank Negara Indonesia Persero Tbk in 2016 of 0.2361 and the maximum value of DER at PT Bank Tabungan Negara Persero Tbk in 2015 amounted to 11.3958. The average value of DER of state-owned enterprises in 2013-2016 amounted to 2.9122. This shows the average proportion of total debt owned by stateowned enterprises is very high exceeds $100 \%$ of the total equity owned by the company which means that most of the financing in state-owned enterprises is financed from corporate debt.

\section{Hypothesis testing}

Based on table 3, the regression model can be formulated as follows.

VALUE $=-0.838+0.289 \mathrm{IC}+0.969 \mathrm{CSD}+2,246 \mathrm{CG}$ - 0.023 UK - 0,113 LEV + e

\section{Discussion}

\section{Intellectual Capital Influence on Corporate Value}

The coefficient of intellectual capital is positive 0,151 and has sig value. of 0.000 which means less than 0.05 . This shows that Hal can not be denied, which means intellectual capital has a positive influence on the value of the company. The results of this study are consistent with Berzkalne and Zelgalve (2014) and Nuryaman (2015) stating that intellectual capital has a positive influence on firm value.

\section{The Effect of Corporate Sustainability Disclosure on Corporate Value}

Corporate sustainability disclosure coefficient is positive 0,243 and has sig value. of 0.286 which means greater than 0.05 . This indicates that $\mathrm{Ha} 2$ is rejected which means corporate sustainability disclosure has no effect on company value. The results of this study are consistent with Gherghina and Vintila (2016), Kurniasari and Warastuti (2015), Moeljadi (2014), and Putu, et.al (2014) stating that corporate sustainability disclosure has a positive influence on firm value.

\section{The influence of Corporate Governance on Corporate Value}

Corporate governance coefficient is positive 0,202 and has sig value. of 0.441 which means greater than 0.05 . This indicates that $\mathrm{Ha} 3$ is rejected which means corporate governance has no influence on company value. The results of this study are consistent with Haryono and $\mathrm{Pa}-$ minto (2015) which states that corporate governance has no influence on corporate value. The results of this study contradict the agency theory stating that corporate governance mechanisms can reduce the agency costs incurred by the company.

\section{Company Size and Leverage to Corporate Value}

The coefficient of firm size is negative at -0.023 and has sig value. amounting to 0.764 , which means sig is greater than 0.05 , which means that the size of the company has no influence on the value of the company. The coefficient of leverage is negative at -0.113 and has a sig value. of 0.000 which means less than 0.05 , which means leverage has a negative effect on the value of the company.

\section{Managerial Implication}

Implementation of intellectual resource management ie capital, human resources, and structural capital that can be optimally utilized can help facilitate the company. Companies with high share demand in the fulfillment of all stakeholder interests can increase the value of the company.

The results of this study support the theory of legitimacy that states that companies that disclose information of social responsibility will gain legitimacy from society 
can increase the value of the company. Companies that have high corporate sustainability disclosure will encourage management to provide more detailed information and broadly related to social responsibility information so as to convince investors in increasing stock demand.

Corporate governance does not affect the value of the company because the company prioritizes on policies that provide more direct benefits for the company, so that managers do not attempt more broadly to increase productive activities in order to maximize corporate value through corporate governance disclosure. In addition, the company can not only conduct corporate governance policy due to its mandatory disclosure nature, but it is expected that the company can further enhance investor confidence further with the disclosure of strategic planning and policy information more effectively increase the company value.

\section{Conclusion, Suggestion, and Limitations}

\section{Conclusion}

1. Intellectual capital has a positive influence on firm value. The results of this study are consistent with Berzkalne and Zelgalve (2014) and Nuryaman (2015).

2. Corporate sustainability disclosure has a positive effect on company value. The results of this study are consistent with Gherghina and Vintila (2016), Kurniasari and Warastuti (2015), Moeljadi (2014), and Putu, et.al (2014).

3. Corporate governance has no effect on corporate value. The results of this study are consistent with Haryono and Paminto (2015). The results of this study are not consistent with Moeljadi (2014) and Putu, et.al (2014).

\section{Suggestion}

1. For companies, should be able to apply reporting in an integrated manner in order to improve the rationalization of investment decisions made by investors.

2. For regulators, it should be possible to fully oblige public companies to implement sustainability reporting in the reporting of social responsibility activities based on GRI G.4 Guidelines to increase corporate value in the future.

3. For the government, it is better if all sectors of the State-Owned Enterprises (SOEs) can increase the value of the company through comprehensive reporting in order to increase investor interest in investing in public sector companies.

4. For subsequent research, researchers can specialize in one sector of the company for the results of research can be more reliable and add other independent variables that can predict the value of a better company.

\section{Research Limitations}

1. Researchers examine the sector of state-owned enterprises with different business sectors that generalize the results of research.

2. The researcher uses three independent variables in predicting the dependent variable with adjusted r-square obtained at $66.1 \%$. This shows that there are still $33.9 \%$ variation of dependent variables that can be explained by other independent variables.

\section{References}

Berzkalne, I., dan E. Zelgalve. 2014. Intellectual Capital and Company Value. Procedia Social and Behavioral Science, 110 : 887-896.

Dewi, K., dan Monalisa. 2016. Effect of Corporate Social Responsibility Disclosure on Financial Performance with Audit Quality As A Moderating Variable. Binus Business Review 7(2) : 149-155. Gherghina, S.C.2015. Corporate Governance Ratings and Firm Value : Empiritical Evidence from The Bucharest Stock Exchange. International Journal of Economics and Financial Issues 5 (1) : 97-110.

Gherghina, S.C., dan G. Vintila. 2016. Exploring The Impact of Corporate Social Responsibility Policies on Firm Value : The Case of Listed Companies in Romania. Economics and Sociology 9 (1) : 23-42.

Global Reporting Initiative. 2013. G4 Sustainable Reporting Guidelines: Standard Reporting and Disclosure Principles. www.globalreporting.org Haryono, U., dan A. Paminto. 2015. Corporate Governance and Firm Value : The Mediating Effect of Financial Peformance and Firm Risk. European Journal of Business and Management 7 (35) : 18-24.

Jensen, M.C dan J.H. Meckling. 1976. Theory of Firm : Managerial Behavior, Agency Cost, and Ownership Structure. Journal of Financial Economics 3 : 305-360.

Kamath, G. B. 2015. Impact of Intellectual Capital on Financial Performance and Market Valuation of Firms in India. International Letters of Social and Humanistic Sciences 48 : 107-122.

Komite Nasional Kebijakan Governance. 2006. General Guidelines of Good Corporate Governance Indonesia. Jakarta

Kurniasari, W., dan Y. Warastuti. 2015. The Relationship Between CSR and Profitability to Firm Value in Sri-Kehati Index. Journal of Economic Behaviour 5 : 31-42.

Moeljadi. 2014. Factors Affecting Firm Value : Theoritical Study on Public Manufacturing Firms in Indonesia. South East Asia Journal of Contemporary Business, Economics, and Law 5 (2) : 6-15. 
Nadeem, S.A., A. Waheed, dan H. Mahmood.

2016. Impact of Leverage and Managerial

Skills on Firm Peformance. Academic Research International 7:175-187.

Nuryaman. 2015. The Influence of Intellectual Capital on The Firm's Value with The Financial Performance as Intervening Varable. Procedia Social and Behavioral Science.

Organization for Economic Cooperation and Development. 2004. OECD Principles of Corporate Governance. Perancis : OECD Publication Service.

Putu, N.N.G.M., Moeljadi, Djumahir, dan A. Djazuli. 2014. Factors Affecting Firm Value of Indonesia Public Manufacturing Firms. International Journal of Business and Management Invention $3,(2): 35-44$.

Setiawan. 2017. During 2016, Bank Mandiri's share price jumped 29 percent.

http://bisniskeuangan.kompas.com/ $\mathrm{read} / 2017 / 01 / 25 / 140000926 /$ selama.2016.harga. saham.bank.mandiri.melonjak.29.persen. 